\title{
Endangered collections
}

\author{
Philadelphia's venerable \\ natural history museum is \\ teetering on the brink of \\ financial disaster. A new \\ president recently took the \\ helm, but can he save one of \\ America's great institutions? \\ Rex Dalton reports.
}

\section{$\mathrm{T}$} he Academy of Natural Sciences in Philadelphia is best known for its vast natural history collections from some of America's founding pioneers: Benjamin Franklin, Thomas Jefferson, Meriwether Lewis and William Clark. But a visitor today might meet some decidedly less august figures coming through the door: express packages full of snails and slugs, sent to the museum regularly from pest inspectors at US borders.

When North America's first natural history museum was founded in 1812, no one envisaged that it would one day end up fighting invasive species. But the centuries have shown the huge importance of the academy's collection of 17 million specimens. Academy scientists rely on its vast holdings and library to identify animals and plants that have crept into new areas, and their expeditions have extended into farflung corners of the world. Last year, for instance, a researcher from the academy reported finding the Tiktaalik fossil - a veritable missing link in the evolutionary journey from water to land some 375 million years ago - on a near inaccessible island off Greenland ${ }^{1}$.

Yet despite the academy's rich history and modern discoveries, it is struggling to survive. Last year, financial problems prompted it to sell 18,200 specimens from its historic mineral and gem collection - a decision that became public at the same time as the city hosted Geological Society of America's annual meeting. The move infuriated scientists, many of whom saw it as selling off a

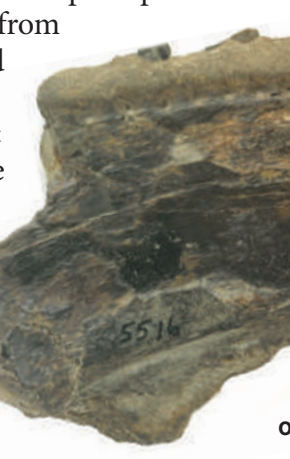

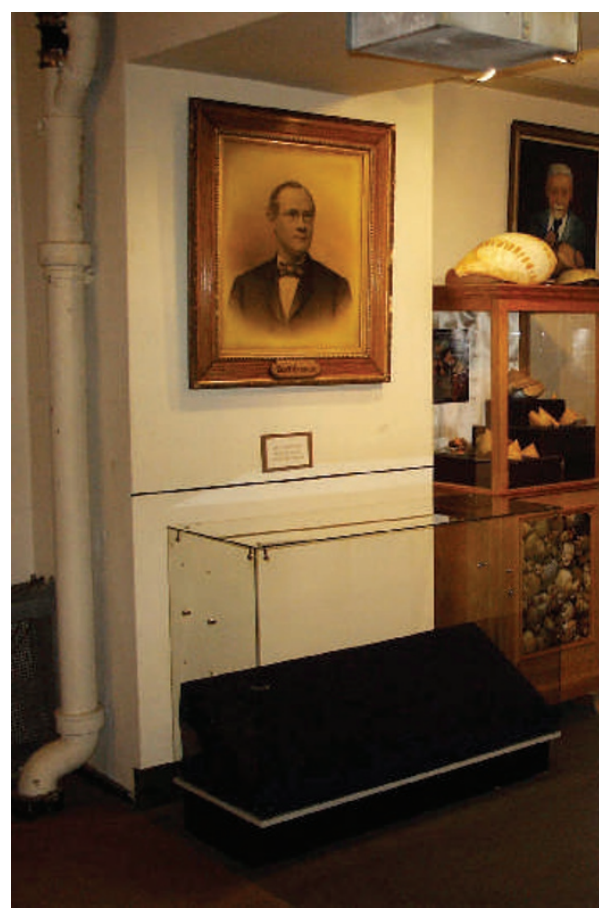

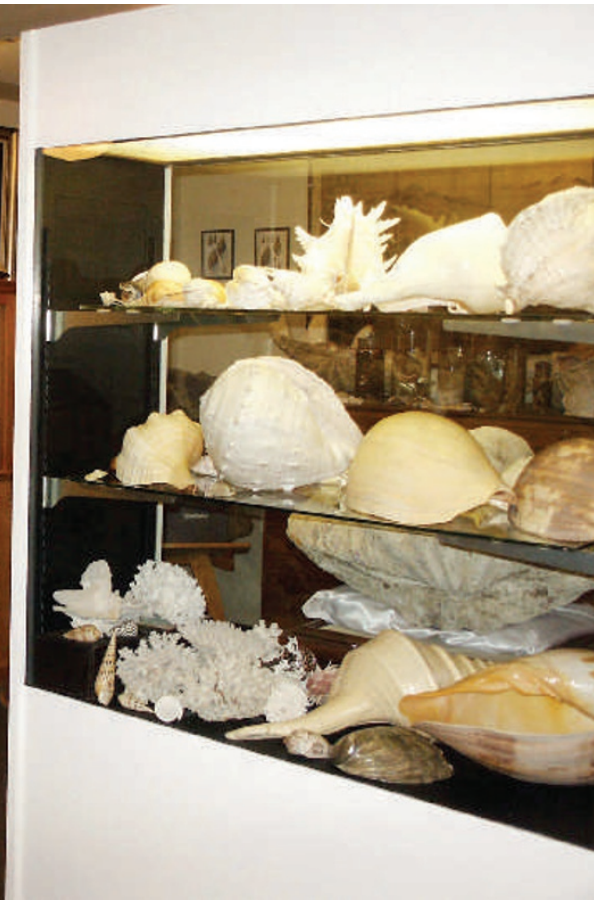

precious piece of history.

Now, though, the sale seems to have marked the academy's low point. A new president, William Brown, arrived at the helm in January, bringing with him a strong background of having righted a previously troubled museum. For the past five years Brown, an ornithologist with a law degree from Harvard, served as president of the Bishop Museum in Honolulu, the official state museum of Hawaii. During his term, Brown extricated the museum from its

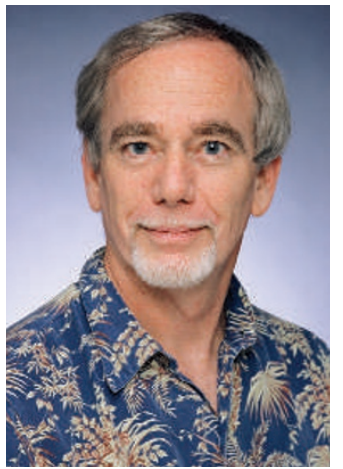

William Brown has a history of rescuing museums. million, some say that the academy's endowment is lower than it needs to be to support a research institution of its size. For the past decade, academy deficits have averaged some $\$ 700,000$ a year, although it did end up $\$ 2$ million in the black for 2005 on its \$17-million operating budget. The debts have taken their toll on staff; over the past ten years, curators have been laid off in waves, with three of the ten remaining being laid off in 2005 .

The mineral sale netted the academy more than $\$ 1$ million, financial and public-relations challenges. "He really left the museum in a better place," says Haunani Apoliona, a Bishop board member who is also an elected trustee of the state's Office of Hawaiian Affairs. "Everyone is sorry to see him move on."

Brown seems to have his work cut out for him in Philadelphia. "The academy has been waiting for someone like Bill for a long time," says museum trustee Thomas Lovejoy, a biologist and president of the Heinz Center, a progressive advocacy institute in Washington DC. "There is plenty for him to do, particularly attending to a bruised staff that has been through some rough years."

Financial woes are the first of many problems. At about US\$55 which will be used to bolster its renowned library. But with Brown now in place, a proposed sale of another 7,300 specimens has been halted. This collection of North American minerals was donated by the Vaux family nearly 125 years ago, who stipulated that they must never be sold. That kept the collection out of the October sale, and now Brown and academy scientists are drawing up plans to exhibit the minerals for the first time in decades. Many academy scientists are relieved; selling the Vaux collection on top of the other minerals, says palaeontologist Ted Daeschler, would have been "too horrible to swallow".

In private, many academy scientists lay part of the blame for the museum's desperate financial straits on its board of trustees - a typical mix of local business executives, community leaders and a few scientists. Some academy staff say that board members were well-meaning but sometimes uninformed, which hindered their ability to engage fully in the museum's problems.

Academy staff have also faced tough times with the museum's presidents. Before Brown's of America's founding pioneers. 
arrival, administrators sometimes threatened to fire anyone who spoke out publicly about the museum's problems. Brown's predecessor, former US oceans chief James Baker, left in April 2006 after serving for four years. Administrator Ian Davison then stepped in to act as chief executive temporarily, overseeing the mineral sale among other changes.

\section{Troubled times}

The academy is not the only museum facing tough times (see page 594). In recent years, natural history museums in the United States have struggled to survive in the face of diminishing government support, competition from the entertainment industry, and lack-lustre philanthropy. Some have taken what scientists deridingly call the theme-park approach — glitzy exhibits to pull in paying crowds, while the scientific mission is reduced if not all but eliminated.

Museums have also used varying approaches to pay back bonds issued for refurbishment, such as increasing their revenue with community dinners or party events, and bringing in star-quality exhibits to boost attendance. For instance, the Houston Museum of Natural Science is taking the controversial step of creating a touring exhibit that includes the real skeleton of Lucy, the famed 3.2-million-year-old hominid from Ethiopia ${ }^{2}$.

Brown comes to Philadelphia with a reputation as a savvy financial manager. At the Bishop Museum, he accelerated programmes to rent out museum locations for parties. "We went from $\$ 50,000$ to a $\$ 1$ million a year in revenue," he says. And although Philadelphia isn't exactly sunny Honolulu, the downtown part of the city is undergoing a major redevelopment, offering new revenue opportunities from businesses and visitors.

Brown also comes with a track record of smoothing over museum disputes. When he took on the position at Bishop, the museum was embroiled in its own volatile controversy - about 80 priceless Hawaiian artefacts had been illegally spirited away and hidden in an isolated cave by indigenous traditionalists. By the time Brown departed, he had managed to help secure the return of the specimens, after a lengthy legal battle.

Brown's predecessor at the academy had sanctioned numerous employees with letters in their personnel files for speaking out publicly about the dispute. "I went through all the files, pulled out the letters and did a blanket pardon," says Brown. Those involved appreciated his openness. "When he walked in, the artefact dispute was really bubbling over," says Apoliona. "His efforts were really honourable. Everything was transparent."

In Philadelphia, Brown will face the challenge of maintaining the remaining staff. Some of those who haven't been fired have left of their own accord, such as renowned botanist Lucinda McDade. She left the academy last year to be research director at the Rancho Santa Ana Botanic Garden in Claremont, California. "I really missed the teaching," she says. In Philadelphia, almost no graduate-education programmes are associated with the academy, even though it has plenty of top universities nearby, such as the University of Pennsylvania.

Brown says that he is interested in exploring the possibility of bolstering graduate programmes. "The academy has many positive aspects," he adds. "It is clear we need to get all the cylinders firing effectively." He knows the academy's legacy well; he studied there briefly as a young scientist, was on the board between 1987 and 1993, and remained an adviser in recent years. His experience with government funding agencies will also come in handy - he was science adviser to Bruce Babbitt, secretary of the US Department of the Interior under President Bill Clinton.

Brown will have a portfolio of top scientists to handle. In addition to Daeschler, who discovered the Tiktaalik, academy ichthyologist John Lundberg is completing a family tree of the catfish, a creature that can be found on every continent ${ }^{3}$. He, together with the academy's Mark Sabaj and their colleagues, regu-

Pink fairies (Clarkia pulchella) were named after William Clark.

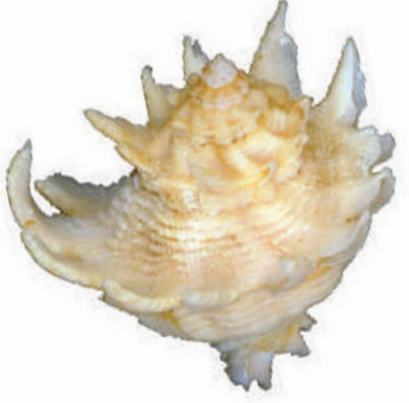

The Academy of Natural Sciences has a collection of around 10 million molluscs.

larly plies the waters of the Americas, Africa and Asia, confirming previous sightings and discovering new species. The team expects to identify 1,750 new species, which will push the total number of catfish species up to 4,600 .

\section{Illegal immigrants}

Elsewhere at the academy, the malacology collection - of snails, slugs, clams and various other molluscs - includes 10 million specimens, some of which date to the 1700s. These specimens, along with the library, help malacologist David Robinson to guard ports of entry for the US Department of Agriculture. It is his express packages that arrive at the academy, at a rate of up to 60 a day, full of invasive species. The crawlers and sliders try to slip in across the border in shipments of marble, tiles, stones, manufactured goods, produce, plants, and even military vehicles - arriving from all continents. When the border inspectors can't identify the species, they send them to specialists such as Robinson for help.

Because he spends so much of his time identifying unknown critters, Robinson rarely publishes on the rare and unusual species he discovers - like one in 1999. That express package contained dried plants collected by scientists from the Missouri Botanical Garden in St Louis and flown from Bali to the port of entry near San Francisco. Buried in the leafage was a lone dead snail. Robinson was stumped: "I didn't have a clue what it was for months."

Then, leafing through a publication ${ }^{4}$ one day, he spotted the Bali native (Anaglyphula whitteni vermeulen) and was finally able to identify his specimen. And Robinson's work on that snail is but one example of how a longstanding academy can help scientists in the new century to fight invading pests.

Rex Dalton is Nature's West Coast correspondent.

1. Daeschler, E. B., Shubin, N. H. \& Jenkins, F. A. Nature 440, 757-763 (2006)

2. Dalton, R. Nature 444, 8 (2006).

3. Lundberg, J. G. Neotrop. Ichthyol. 3, 597-605 (2005).

4. Vermeulen, J. J. Basteria 59, 149-162 (1996). 